\title{
Y chromosome fuels dynastic dilemma
}

\section{TOKYO}

Politicians and legal experts debating whether to allow females to inherit the Japanese imperial line have consulted geneticists for advice. A government advisory committee considered whether the passage of an intact Y chromosome down a male line of descent might be a scientific argument for the male-only descent system. They concluded, however, that assigning rights to the throne on the basis of the $\mathrm{Y}$ chromosome would give a claim to many ordinary citizens.

The incident shows how desperate Japanese politicians are to resolve the problem of Japan's emperor, the latest in what may be the world's longest unbroken imperial line, having no male heir. When Emperor Akihito dies, the throne will pass to his two sons. But it's unclear what will happen after that. His grandchildren are all female, and at ages 39 and 42 , the princes' wives are running out of time to produce a boy.

Prime Minister Junichiro Koizumi has thrown his weight behind an amendment to allow the oldest child of either sex to inherit the throne. This would allow the four-year-old daughter of the eldest prince to be next in line. Last year, Koizumi vowed to propose the amendment during the parliament's current session, which began on 20 January.

Nature has learned that in a series of cabinet meetings held ahead of Koizumi's pledge, politicians, historians and legal experts called on scientists for advice. Some experts, vigorously opposed to the idea of allowing females to pass on the line, used the $\mathrm{Y}$ chromosome to support their argument.

Government records show that committee member Hidetsugu Yagi, an expert in constitutional law at Takasaki City University of Economics, referred to the "stamp of the Y chromosome", and the need to preserve it.



Desperate for a boy: Emperor Akihito (second from left) is still without a grandson to inherit the throne.

Analogous pairs of all the other chromosomes swap genetic elements, which disrupts the integrity of the DNA sequences. But only $5 \%$ of the Y chromosome combines with the $\mathrm{X}$ chromosome; the rest is conserved. This means the Y chromosome has unmatched genetic integrity and forms an ideal marker for the male line (see 'Tracing a Y chromosome through 100 generations').

"In a male-descent system, even a distant relative will have inherited the same Y chromosome," said Yagi. "Of course our ancestors didn't have this knowledge of genetics, but they would have known that blood can be inherited."

But the argument backfired, when Akinori Takamori, a historian of ancient Japan at Takushoku University in Tokyo, told the meeting that if the Y chromosome were so well conserved, it would also have been passed down a countless number of splinter lines over the past 1,000 years. "The distinction between the average citizen and the imperial household would become uncertain," he says. Isao Tokoro, an expert in Japanese legal history at Kyoto Sangyo University, Kyoto City, agreed: "I don't think the 'stamp of the Y chromosome" is very meaningful here."

So the Y-chromosome argument did not make it into the committee's final report. After receiving the advice in November, Koizumi promised to push for a gender-neutral amendment in this season's parliament - a measure apparently supported by $80 \%$ of the population.

The situation was confused earlier this month, however, by the announcement that the second prince's wife was 6-weeks pregnant. With the possibility of a male heir within the imperial line, conservatives are pushing Koizumi to postpone the issue, something he looks set to do.

David Cyranoski

\section{Tracing a Y chromosome through 100 generations}

Those justifying a male-only system routinely refer to an unbroken male line of 125 generations since Japan's first emperor Jimmu. Although the first ten or so generations are probably mythical, and there may have been a break after the 25th emperor, Japanese historians say they are confident that the line has been continuous (if not always directly father-to-son) for 100 generations, or since about 500 AD.
If that's true, the imperial $Y$ chromosome should be largely conserved, say geneticists. Accumulated point mutations are probably negligible, and although inversions and deletions might have built up, the sequence should still be recognizable, says geneticist Yutaka Nakahori of Tokushima University.

A genetics expert consulted by the government committee told Nature that digging up emperors to analyse their DNA could show how far the $Y$ chromosome stretches back, how much it has changed in that time, and whether the line has ever been broken. But he says he doesn't want to be named, much less involved in such a project, for fear of being "assassinated". And Mark Jobling of Leicester University, UK, who studies Y-chromosome evolution, says that most nuclear DNA from 1,500 years ago would have deteriorated: "You would be very lucky to get good $Y$ data from your ancient emperor."

An alternative to digging up graves would be to trace a tree of the imperial family by comparing the $Y$-chromosomes of distant living relatives to estimate when the oldest family member would have lived. Nakahori says he would love to do this, but realizes it would never be allowed by the Imperial Household Agency, which keeps a jealous guard on such matters.

D.C. 